\title{
Digital Space. The library of the future occupying the present
}

\author{
Nathalia Machado Cardoso ${ }^{1}$
}

"Virtual books" will no longer face the problems of their physical counterparts and will be duplicated as many times as desired. The library itself will be "infinite"...(P. Z. M.) $)^{2}$

ith passing years, it seems that the old
habit of visiting large libraries with never-ending shelves of books on the most varied topics is becoming increasingly more rare, with preference for the use of the so-called Virtual Libraries. This is a phenomenon that is not limited to any particular area of knowledge, since we can find at no cost on the internet both the complete works of Machado de Assis and the latest discoveries in any and all branches of science.

Searching for an explanation for the impact of technology on the generation, publication and availability of documents based on computer technology, Landoni et al. ${ }^{1}$ have divided the history of libraries into three main periods: the traditional library (from Aristoteles to the beginning of library automation], the modern or automated library lin which computers were used for basic services such as cataloguing and organization of the collection], and finally the electronic library (the library of the future, conceived as a new strategy for information retrieval, where the complete text of documents is available on-line]. This library can be accessed remotely from any location by means of a computer network, favoring universal accessibility. In this revolutionary conception, "virtual books" will no longer face the problems of their physical counterparts and will be duplicated as often as desired. The library itself will be "infinite" since there will be no limit to the number of books it may contain, as long as it is structured and made available through powerful computers interconnected with high speed networks. ${ }^{2}$

As an important part of this movement in the health area, we point out the digital content, available in our country, in the Virtual Health Library (VHL), a program that became consolidated as a strategy of the Pan American Health Organization (PAHO) for technical cooperation in scientific health information in Latin America and the Caribbean, and which consists of national systems operating networks of libraries and of centers of documentation in health sciences. The VHL is the result of the evolution led by the Latin American and Caribbean Center of Health Science Information and was created in the 1990's during the IV Regional Congress of Health Science Information (CRICS4) held in 1998 in San José, Costa Rica.

The creation of VHL clearly showed the phase of convergence of the model of information management and health information exchange for the para-

1. Undergraduate Medical student and Monitor of the Digestive Surgery Division, Department of Surgery and Anatomy, FMRP-USP, Ribeirao Preto-SP, Brazil 
digm of the Internet, as a means of production of sources and flows of scientific and technical information. The network was constructed in a cooperative manner, strengthening capacities and infrastructures and facilitating ample access to information for the permanent improvement of health and for the development of the Region in a sustainable manner. During the same period, the Regional Library of Medicine [BIREME], with the support of the the Agency for the Support of Research of the State of São Paulo (FAPESP], created SciELO - Scientific Electronic Library Online, as a model for the cooperative electronic publication of scientific journals on the Internet in an open access modality ${ }^{3}$

The most incredible feature within the VHL concept is that the process of democratization of knowledge was elevated to its maximum degree since the Internet is increasingly present as a great vehicle of communication in science. The easy access to scientific journals on the Internet has led even the most resistant persons, who defended the old paper model as the main recording site for information, to surrender to the novelty. The result is that, in 2007, the average number of monthly accesses to the regional site of $\mathrm{VHL}$ and Scielo was 7 million and more than 120 million accesses/year are estimated for the network as a whole, revealing that $\mathrm{VHL}$ is one of the major world initiatives regarding scientific and technical information. ${ }^{3}$

This evolution of communication is not a simple change from paper support to digital support, but a new model of production of the flow of information in the scientific community, with the emergence of movements for open access publication and self-archiving, which favor equitable access to scientific knowledge. ${ }^{2}$ Within this context, we may emphasize three important points that contribute significantly to the success of the model: the time between submission of a paper and its availability for access on the part of users is minimized; all published papers can be universally accessed at any time regardless of the place where the user is; visibility and accessibility can be maximized. ${ }^{4}$ In other words, the process starts with the execution of the study in itself and ends with its publication and dissemination to the scientific community. It has become much more rapid and accessible, accompanying the natural evolution of the means of communication and showing that science has much to gain from the facility of the flow of information in the digital world.

And today the reality is different. We are getting used to facing a never ending quantity of computers when we enter a virtual library and to navigate in an infinite world. These are different times.

\section{References}

1. Monica Landoni, Nadia Catenazzi, Forbes Gibb, (1993) "Hyperbooks and visual-books in an electronic library", Electronic Library, The, Vol. 11 Iss: 3, pp.175-86.

2. Marchiori, Patricia Zeni. "Ciberteca" ou biblioteca virtual: uma perspectiva de gerenciamento de recursos de informação. Ci. Inf. [online]. 1997, vol.26, n.2 [cited 2013-04-16]. Available from: <http://www.scielo.br/scielo.php?script= sci_arttext\&pid=S0100-19651997000200002\&Ing= en\&nrm=iso >. ISSN 0100-1965. http://dx.doi.org/10.1590/ S0100-19651997000200002.

3. http://modelo.bvsalud.org/vhl/historia-da-bvs/

4. Packer, Abel Laerte. (2005). A construção coletiva da Biblioteca Virtual em Saúde. Interface - Comunicação, Saúde, Educação, 9(17), 249-72. Recuperado em 16 de abril de 2013, de http:// www.scielo.br/scielo.php?script=sci_arttext\&pid=S1414$32832005000200004 \&$ Ing=pt\&tlng=pt. 10.1590/S141432832005000200004 